\title{
MODELS AND INTERACTION OF INTENSIVE TRAINING AND SPORT PERFORMANCE OF 14-15-YEAR-OLD ATHLETES IN RHYTHMIC GYMNASTICS
}

\author{
Renata Rutkauskaitė, Antanas Skarbalius \\ Lithuanian Academy of Physical Education, Kaunas, Lithuania
}

\begin{abstract}
Research background and hypothesis. The efficacy of athlete's sport performance depends on the targeted training in certain periods, organization, management, individual adaptation of an athlete to the loads of training and competitions.

Research aim of this work was to determine the impact of intensive training on sport performance of 14-15 year old athletes in rhythmic gymnastics and their optimization.

Research methods. The experiment resulted in modeling two different training programs and establishing the structure of the content of the training programs, as well as athletes' sports performance. The training loads protocols registered the time for choreography, element mastering, competitive routines and athletic training in each training session. The efficacy of the training programs was established registering the realization of competitive activities under competitive conditions according to the number of points received by the gymnast of each training program and according to the place won. When we tried to establish if the training sessions and competitive loads matched the specificity of competitive activities, we registered the changes in the athletes' heart rate during different training sessions.

Research results. Training of athletes in two training programs was different - their training loads were not significantly different - from 672 to 697 hours a year, as well as the indices of the training days - from 5.4 to 5.6 days a week, but the training content differed significantly. In most effective training program choreographic training dominated $(30.9 \%)$. Statistically significant differences $(p<0.05)$ were found in the indices of explosive strength and muscular power, specific endurance and coordination movement abilities. At the beginning of the season and at the end of it the realization of the body movement technique performing routines with different tools was not different $(p>0.05)$.

Discussion and conclusion. Sports performance of 14-15-year-old athletes in rhythmic gymnastics was mostly influenced by the time for mastering competitive routines $(\mathrm{r}=0.836)$; however, the research did not establish differences in intensifying training. Besides the importance of integral athletic fitness, explosive strength, and strength endurance, the research established the significance of aerobic fitness $(r=0.704)$ for sports performance. Moreover, the significance of body composition indices increased in comparison with previous training years: body height $(\mathrm{r}=-0.819)$, body weight $(\mathrm{r}=-0.657)$, and BMI $(\mathrm{r}=-0.836)$.
\end{abstract}

Keywords: rhythmic gymnastics, training, performance, metamodel.

\section{INTRODUCTION}

$\mathrm{R}$ ational harmonization of training loads and intensity time is a precondition of successful management of training athletes (Mester, Perl, 2000). It depends on the targeted training in certain periods, organization, management, individual adaptation of an athlete to the loads of training and competitions (Mester, Perl, 2000; Edelmann-Nusser et al., 2002). If the requirements of athlete training mentioned above are followed, there are premises for their successful participation in the most important international competitions.

While registering and analyzing competitive activities it is possible to establish the level of their interaction with different components of athlete 
training (Mester, Perl, 2000; Edelmann-Nusser et al., 2002; Avalos et al., 2003; Perl, 2004; Bügner, 2005; Hellard et al., 2006). Besides, registering and analyzing competitive activities enable us to foresee the tendencies of a sport, forecast sports results, and plan the trends of athlete training. J. Perl (2001, 2004) called this interaction of training loads and performance the Metamodel - the theoretical interaction of training and sport performance - when we need to find an optimal model of athlete training which would allow achieving the highest level of sport performance.

Rhythmic gymnastics is a sport which requires early selection of athletes (Лисицкая et al., 1982; Balyi, 2001; Карпенко, 2003; Balyi, Hamilton, 2004), intensive training in the periods of childhood and adolescence (Jastrejembskaia, Titov, 1999; Карпенко, 2003) and early termination of the sports career (Стамбулова, 1999). In the period of sports performance perfection and seeking for high sports results (Лисицкая и др., 1982; Douda et al., 2002; Карпенко, 2003) the training loads of 14-15-yearold athletes in rhythmic gymnastics become greater and more intensive (Fan et al., 2004).

Most research of this kind has been carried out in swimming (Edelmann-Nusser et al., 2002; Avalos et al., 2003; Bügner, 2005; Hellard et al., 2006) and track-and-field athletics (Banister et al., 1999). In our previous research (Rutkauskaite, Skarbalius, 2009, 2011) the adaptation to physical loads, intensity of training loads and competitive activities of the rhythmic gymnastics have been studied, but for 11-14-year-old gymnasts. That is why the aim of this work was to determine the impact of specific training on sport performance of 14-15-year-old athletes in rhythmic gymnastics.

\section{RESEARCH METHODS}

Subjects and experiment design. The research involved the training of 14-15-year-old athletes $(n=10)$ in rhythmic gymnastics from the National and Kaunas city teams (Lithuania) (Table 1). The experiment resulted in modeling two (A and B) different training programs (5 gymnasts in each training program) and establishing the structure of the content of the training programs for all macrocycle (48-week duration), as well as athletes' sports performance. The training loads protocols registered the time for choreography, elements learning, competitive routines and athletic training in each training session (Лисицкая и др., 1982; Jastrjembskaia, Titov, 1999).
The efficacy of the training programs was established registering the realization of competitive activities under competitive conditions, according to the number of points received by the gymnast of each training program, according to the place won (the points awarded in the descending order). Participation of gymnasts in competitions was different because not all of them succeeded in winning the right to participate in more important competitions - national and international.

Research hypothesis $\left(\mathrm{H}_{0}\right)$ was that different training programs (Tables 2 and 3) have the same impact on sports performance. The alternative hypothesis was that different training programs have different impact on sport performance $\left(\mathrm{H}_{1}\right)$. Independent variables were the duration, content, volume, intensity of training loads, and the dependent variable was athletes' sport performance.

The following research methods were used in this research:

- Anthropometry. Height in the standing position and body mass components (body mass, body mass index BMI, subcutaneous body fat layer in percent (\%), and kilograms $(\mathrm{kg})$ )(TANITA BODY ANALYSER TBF300);

- Physical fitness. Athletic fitness of female athletes was estimated applying tests of flexibility (tests of "bridge" and "splits"), complex abilities of flexibility and balance (test of "leg keeping"), muscular endurance (push-ups, sit-ups and lifting legs), specific endurance (test of "jumping into rope with double turns"), coordination abilities ("10 seconds running into the rope") and explosive strength (standing long jump on both feet). Research presented absolute values of estimation of movement abilities, and the values estimated in points. The integral index estimating athletic fitness was received summing up the points of each test (Лисицкая и др., 1982; Jetrejambskaja, Titov, 1999; Говорова, Плекшань, 2001; Карпенко, 2003).

- Gymnasts' mental fitness (subjective fitness for the competition - self-confidence) was evaluated before each competition. Self-confidence was evaluated applying the methodology based on the DemboRubinschtein scale. Each subject evaluated herself before every competition: 10 points indicated the best mental fitness, and 1 


\begin{tabular}{|l|l|l|l|l|l|}
\hline \multicolumn{7}{|c|}{ Before experiment $(\bar{x} \pm$ SD $)$} \\
\hline \multicolumn{1}{|c|}{ Training groups } & Age, years & Height, $\mathbf{c m}$ & $\begin{array}{c}\text { Body mass, } \\
\text { kg }\end{array}$ & BMI & Body fat, \% \\
\hline A $(\mathrm{n}=5)$ & $14.4 \pm 0.55$ & $172.0 \pm 5.09$ & $54.3 \pm 3.25$ & $18.3 \pm 0.65$ & $13.5 \pm 2.59$ \\
\hline B $(\mathrm{n}=5)$ & $14.2 \pm 0.84$ & $163.4 \pm 4.44$ & $50.0 \pm 3.79$ & $18.7 \pm 1.07$ & $13.6 \pm 3.36$ \\
\hline Mean $(\bar{x} \pm \mathrm{SD})$ & $14.9 \pm 0.67$ & $167.7 \pm 6.39$ & $52.1 \pm 404$ & $18.5 \pm 0.85$ & $13.5 \pm 2.83$ \\
\hline $\begin{array}{l}\text { Kolmogorov-Smirnov } \\
\begin{array}{l}Z \\
\text { test; }\end{array}\end{array}$ & $\begin{array}{l}\mathrm{F}=0.2 ; \\
\mathrm{p}>0.05 * \text { (evel }\end{array}$ & $\begin{array}{l}\mathbf{F}=\mathbf{8 . 0 7} \\
\mathbf{p}<\mathbf{0 . 0 5} *\end{array}$ & $\begin{array}{l}\mathrm{F}=3.81 ; \\
\mathrm{p}>0.05 *\end{array}$ & $\begin{array}{l}\mathrm{F}=0.38 ; \\
\mathrm{p}>0.05\end{array}$ & $\begin{array}{l}\mathrm{F}=0.001 ; \\
\mathrm{p}>0.05\end{array}$ \\
\hline
\end{tabular}

Table 1. Anthropometric characteristics of subjects $(\bar{x} \pm \mathrm{SD})$

Note. * - statistically significant difference between different training programs after the experiment; ** - statistically significant difference after the experiment.

point showed that the athlete was totally unprepared for the competition.

- Changes of gymnasts' technical fitness were registered during competitions according to the declared and realized coefficients of technical fitness - Difficulty values and Artistic values.

- Aerobic capacity. The aerobic capacity of gymnasts was evaluated using the continuously intermittent treadmill test. During the whole research we registered vegetative and gaseous circulation indices with the help of gas analyzers ("Cortex 3B" and "Oxycon Mobile" - Jaeger \& Germany) and heart rate measurement (heart rate measurer with memory Polar S601). 5 minutes after the beginning of the research capillary blood samples were taken from the fingertips to estimate the concentration of lactates using analyzer "Eksan-G Universal" (Kulis et al., 1988).

- The training load intensity were determined using:

- Heart rate measurement - registering heart beat rate using heart rate measurer with memory (Polar Team System; Finland).

- Biochemical blood testing: analyzer "Eksan-G" was used to estimate the concentration of lactates in the blood.

- Pedagogical observation. The competitive activities of gymnasts were recorded using digital video camera $(50 \mathrm{~Hz}$ frequency, Sony Digital 8-TRV320E).

Methods of mathematical statistics. In order to compare the data the mean $(\bar{x})$ and the standard deviation (SD) were calculated. KolmogorovSmirnov test was applied when there were not many tested categories of variables, it was used to evaluate the differences and the statistical significance of value differences. The following significance levels of statistical conclusions were used: $\mathrm{p}<0.05$ - significant; $\mathrm{p}<0.01-$ highly significant; $\mathrm{p}<0.001$ - absolutely significant conclusion. Causal relations were determined applying correlation analysis (Pearson's correlation coefficient $r$ ). The significance of training and fitness factors was established by factor analysis (principal factor analysis communalities $=$ multiple $\mathrm{r}^{2}$ ). All calculations were performed using computer programs MS Excel and STATISTICA. Experimental data were described using 52 variables, 51 of which were the aspects of training and fitness $(\mathrm{X})$ and one was the final indicator of the efficacy of competitive activities (the mean of the points achieved by each gymnast) Y. The principal factor analysis (communalities = $r$ squares) was performed to estimate the interaction of the structure, the content and the volume of the complicated training process and fitness.

\section{RESEARCH RESULTS}

Training. The yearly macro-cycle for training 14-15-year-old athletes in rhythmic gymnastics consisted of 286 training sessions in program B and 302 training sessions in program A. The yearly training load did not differ significantly (from 672 to 697 hours) (Table 2).

No statistically significant differences were established in the number of training days in the competitive and the preparatory periods $(\mathrm{p}>0.05)$. Different kinds of training dominated in different training programs: competitive routines in program A (35.1\%), and choreographic training in program B (30.9\%) (Table 3).

The training intensity in both training programs did not differ significantly during the micro-cycles $(p>0.05)$. Training load intensity was different in different micro-cycles. The most intensive training occurred in the accented micro-cycle (the longest duration of one training session, the biggest sum of heart beats during the whole training session, the highest maximal, average and minimal heart rate). The intensity of the training loads in this micro- 
Table 2. Training loads of different training programs of 14-15-yearold athletes in rhythmic gymnastics

\begin{tabular}{|c|c|c|c|c|}
\hline \multirow{2}{*}{ Parameters of training loads } & \multicolumn{2}{|c|}{ Training groups $(\bar{x} \pm \mathrm{SD})$} & \multirow{2}{*}{$\begin{array}{c}\text { Mean } \\
(\bar{x} \pm \mathrm{SD})\end{array}$} & \multirow{2}{*}{$\begin{array}{l}\text { Kolmogorov- } \\
\text { Smirnov Z test; } \\
\text { p level }\end{array}$} \\
\hline & $\mathbf{A}$ & B & & \\
\hline $\begin{array}{l}\text { Number of training sessions } \\
\text { a year }\end{array}$ & 302 & 286 & $289 \pm 11.31$ & \\
\hline Number of macro-cycle hours & 697 & 672 & $675.6 \pm 77.68$ & \\
\hline $\begin{array}{l}\text { Number of training sessions } \\
\text { a week }\end{array}$ & $5.6 \pm 0.73$ & $5.4 \pm 0.81$ & $5.5 \pm 0.78$ & $\mathrm{p}=0.10$ \\
\hline Number of hours a week & $12.5 \pm 2.70$ & $12.3 \pm 2.44$ & $12.4 \pm 2.56$ & $\mathrm{p}=0.10$ \\
\hline $\begin{array}{l}\text { Number of competitions a } \\
\text { year (from - to, and average) }\end{array}$ & $\begin{array}{c}5-10 \\
7.8 \pm 2.58\end{array}$ & $\begin{array}{c}2-12 \\
8.4 \pm 3.91\end{array}$ & $\begin{array}{c}2-12 \\
8.1 \pm 3.14\end{array}$ & \\
\hline Number of competition days & \multicolumn{4}{|c|}{29 days (duration of loads of competition days $\sim 3 \mathrm{~h}$ ) } \\
\hline
\end{tabular}

Table 3. Content (\%) of training loads of different training programs of 14 15 year old athletes in rhythmic gymnastics

\begin{tabular}{|c|c|c|c|c|}
\hline \multirow{2}{*}{ Content of training loads } & \multicolumn{2}{|c|}{ Training groups $(\bar{x} \pm \mathrm{SD})$} & \multirow{2}{*}{$\begin{array}{c}\text { Mean } \\
(\bar{x} \pm \text { SD })\end{array}$} & \multirow{2}{*}{$\begin{array}{c}\text { Kolmogorov- } \\
\text { Smirnov Z test; } \\
\text { p level }\end{array}$} \\
\hline & $\mathbf{A}$ & B & & \\
\hline Choreography & $26.06 \pm 5.86$ & $30.94 \pm 3.58$ & $28.48 \pm 5.43$ & $\mathbf{p}<0.001$ \\
\hline Elements & $20.59 \pm 5.93$ & $19.90 \pm 4.60$ & $20.25 \pm 5.29$ & $\mathrm{p}>0.05$ \\
\hline Competition routines & $35.06 \pm 12.24$ & $26.84 \pm 9.94$ & $30.99 \pm 11.85$ & $\mathrm{p}<0.001$ \\
\hline Athletic training & $18.27 \pm 5.58$ & $22.30 \pm 6.64$ & $20.27 \pm 6.42$ & $\mathrm{p}<0.001$ \\
\hline
\end{tabular}

cycle was close to the intensity in the competitive period (established in the city competitions). In the accented micro-cycle the heart beat rate of athletes in both training programs was higher than in the competition period activities $(\mathrm{p}>0.05)$.

Sport performance. The most effective program was B (358 points), with dominating time for choreographic training $(30.9 \%)$. At the beginning and at the end of the experiment the integral index of athletic fitness in points did not differ statistically significantly $(p>0.05)$ in both training programs. However, statistically significant differences $(p<0.025)$ were established in the indices of explosive strength, coordination abilities, and specific endurance. After the experiment statistical differences between the training groups were found only in gymnasts' specific endurance $(\mathrm{p}<0.05)$.

At the beginning of the season the realization of body movement with different tools technique was not different $(p>0.05)$, but at the end of the season body movement technique of gymnasts in group A was better (the mean coefficient of technique was 3.82 points) ( $p<0.001)$, compared to group B (3.32). The indices of movement with tools technique in both groups were only slightly different at the beginning of the season $(\mathrm{p}>0.05)$ : from coefficient $3.62 \pm 0.67$ (ribbon) to coefficient $4.60 \pm 0.76$ (hoop) on average. At the end of the season the highest mean coefficients of the difficult movement with tools technique were achieved by athletes in program A $(4.43 \pm 0.88)$.

The indices of aerobic fitness in both programs were not statistically significantly different $(p>0.05)$. In program $\mathrm{A}$ the athletes' maximal oxygen consumption $\left(\mathrm{VO}_{2 \max }-50.46 \mathrm{ml} \cdot \mathrm{min}^{-1} \cdot \mathrm{kg}^{-1}\right)$ was by $2.86 \mathrm{ml} \cdot \mathrm{min}^{-1} \cdot \mathrm{kg}^{-1}$ greater than in program $\mathrm{B}$ (47.60). Though the average $\mathrm{HR}_{\max }$ index of athletes in program E was greater $\left(200.66 \pm 10.51 \mathrm{ml} \cdot \mathrm{min}^{-1} \cdot \mathrm{kg}^{-1}\right)$ than in program A $(196.65 \pm 5.03)$, but the established differences between athletes in both training programs were not statistically significant $(p>0.05)$. In both training programs the general energy consumption in competitive activities was different. Though athletes in the more effective training program $\mathrm{B}$ were more self-confident, the indices of self-confidence of athletes in both training programs differed rather slightly $(\mathrm{p}<0.05)$.

Interaction of training and sport performance. Comparisons of training and fitness models in the experiment were not alienated from each other and did not exceed the critical limits of standard deviation of experimental (research) distribution (diagrammatical representation of model data was performed using SIMCA-P program). It allowed comparing available training models to athletes' training and fitness. The data of summarized values of each gymnasts in the 
experiment were not alienated from each other and did not exceed the critical limits of standard deviation of experimental distribution, but more gymnasts from group B were over average (Figure 1).

The greatest interdependence between the training load (hours per hour) and the body composition was established in the training process in program B. It was found that with the increase of the training load the body weight $(r=-0.384)$, the body fat $(r=-0.116)$ and the body mass index decreased. The impact of training loads for the best athletes in both training groups was controversial: in program A the increased training load diminished the body weight, body fat $(\%)$ and body mass index of the best gymnast, and in program B it was vice versa - all those indices increased. The average athletes' body movement technique in group B was worse than in group $\mathrm{A}$ at the end of the season, but gymnasts in training program $\mathrm{B}$ demonstrated more even body movement and movement with tools technique (Figure. 2).

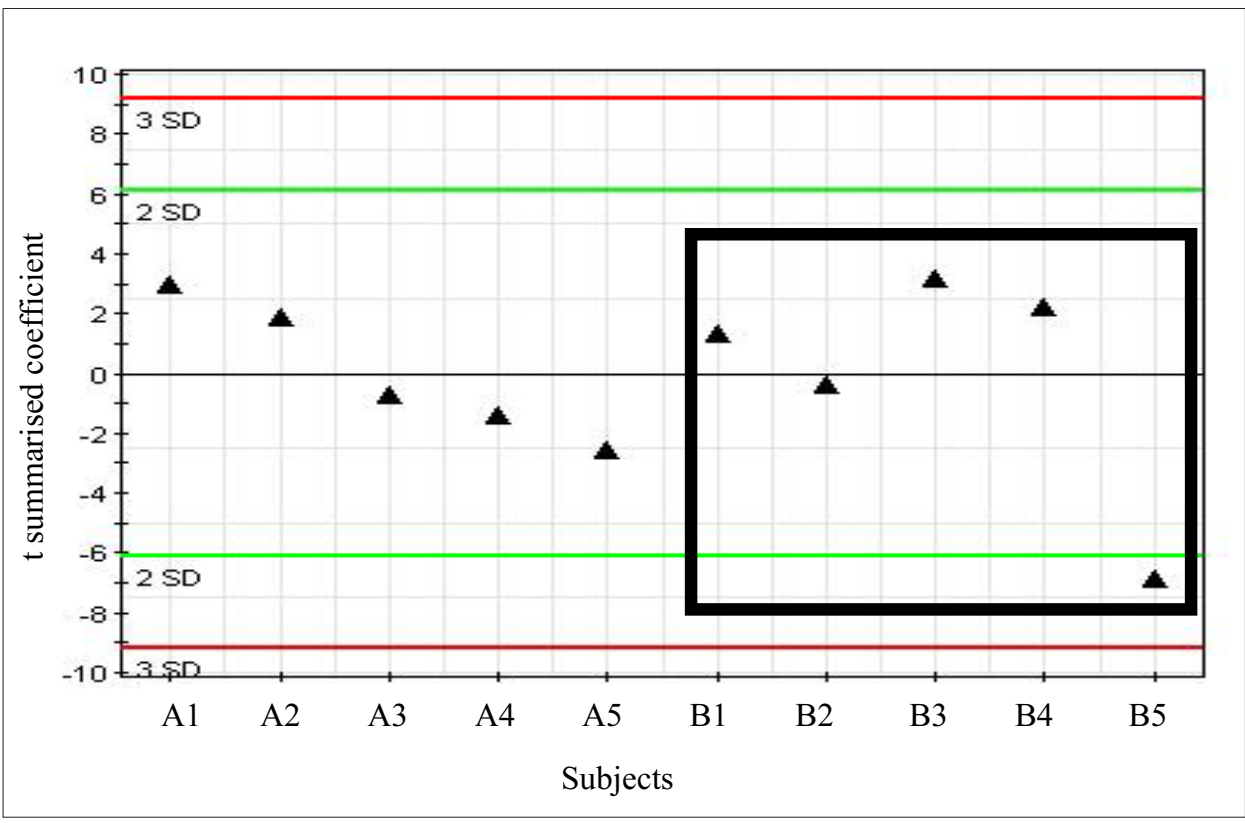

Figure 1. Comparisons of training and fitness models (diagrammatical representation of model data was performed using SIMCA-P program)

Note. Marked are summarized training and fitness variables of most effective training program (B) gymnasts - they are greater than average. A1-A5, B1-B5 - comparison of training and fitness for gymnasts from different training groups. $\mathrm{t}[1]$ variable which summarizes all (training and fitness) variables.

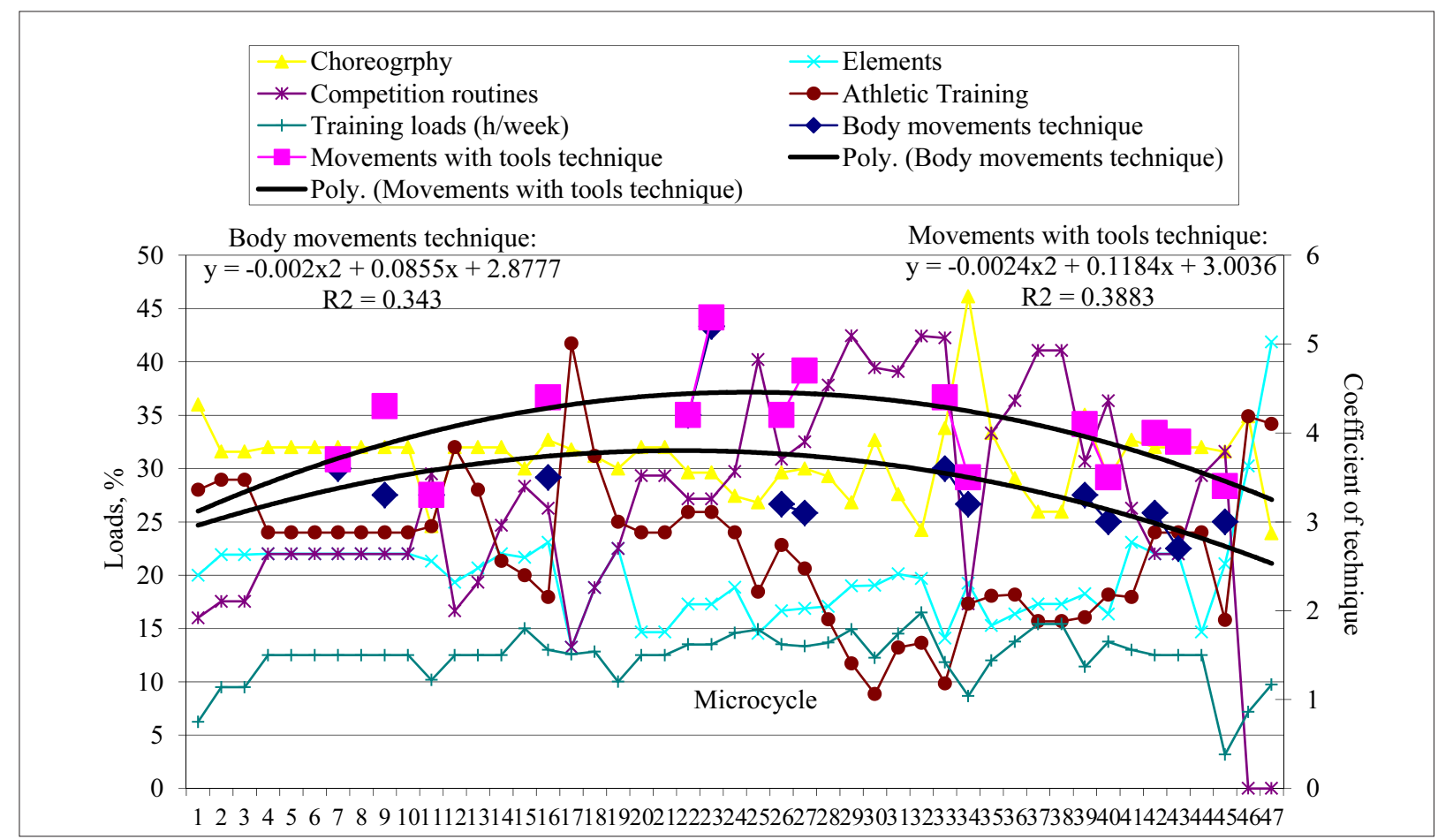

Figure. 2. Changes in the training loads (\%), training content and the difficulty of technique in different micro-cycles in the most effective training program for 14-15-year-old gymnasts in the experiment of athlete training intensification 
Time for mastering competitive routines in program A was effective for body movement technique $(\mathrm{y}=-0.0008 \mathrm{x} 2+0.0551 \mathrm{x}-0.4007$; $\left.\mathrm{r}^{2}=0.5221\right)$, but it was not so effective in program $\mathrm{B}\left(\mathrm{y}=0.0003 \times 2-0.0125 \mathrm{x}-0.0579 ; \mathrm{r}^{2}=0.1421\right)$. Mastering competitive routines, which dominated in program $\mathrm{A}$, influenced movement with tools technique $(\mathrm{y}=-0.0008 \mathrm{x} 2+0.0511 \mathrm{x}-0.3621$; $\left.\mathrm{r}^{2}=0.4659\right)$. However, mastering competitive routines was not so significant for body movement technique for gymnasts in program B $\left(y=0.0004 x 2-0.0069 x-0.2206 ; r^{2}=0.314\right)$.

From the $16^{\text {th }}$ micro-cycle the structure of the most effective training program in the competition period was the following: $30.7 \%$ of choreographic training, $17.8 \%$ of mastering of elements, $31.4 \%$ of mastering competition routines, and $20.1 \%$ of athletic training. Such structure of the training content enabled the 14-15-year-old gymnasts to improve their body movement technique indices by $16.7 \%$, but the movement with tools technique fell off by $5 \%$. It was established that the indices of the difficulty of the technique kept decreasing till the end of the season (the rest 7 micro-cycles). Higher results could have been achieved due to minor changes in the training content and training load in different micro-cycles (Figure. 2).

\section{DISCUSSION}

The trends in the changes of training high performance athletes (Balyi, 2001; Balyi, Hamilton, 2004), specific features of the developments of rhythmic gymnastics (Krug, 1996; Jastrejembskaia, Titov, 1999; Knoll et al., 2000; Карпенко, 2003), as well as the upturn of sports results motivate us to look for new, scientifically grounded sports technologies, methods and forms of training. In this experiment the training loads for athletes were 697 hours in a macro-cycle and 12.5 hours a week (training program A), and 672 hours in a macro-cycle, 12.3 hours a week for program B. Comparing with elite gymnasts (Карпенко, 2003; Худолей, 2004), the training loads were not so high.

The training loads applied to both training programs were rather similar (12.54 hours per week in program $\mathrm{A}$, and 12.27 hours per week in program B), but they had different impact on athletes' technical fitness. Researchers (Hohmann et al., 2000; Perl, 2001) claim that each system reacts differently to the applied impact according to its own adaptation processes, thus the training loads of the same volume and content can have a different impact on athletes sports performance (Perl, 2001, 2004; Bügner, 2005). The worse quality of body movement technique could be explained by the increased body weight of athletes, which might have affected the experts' evaluations (Popovic, 2000; Pietrzyk, 2003).

In this experiment the training programs included choreography (47.91 min 4.08 times a week in program $\mathrm{A}$, and 56.35 min 4 times a week in program B). As some researchers suggest (Лисицкая и др., 1982; Jastrjembskaia, Titov, 1999; Apatow, 2001; Карпенко, 2003) the time for choreographic training should not be reduced because it could cause deterioration in technical fitness. According to J. Perl $(2001,2004)$, the mean variations in the inner systems (sports performance) can be caused by inadequate training loads (Thomas, Busso, 2005). The increased time for mastering competition routines in our experiment (from 18.5 to $46.2 \%$ ) determined the level of technical fitness. On the other hand, reducing training loads and increasing intensity could produce better results (Banister et al., 1999; Kubukeli et al., 2002). In this experiment the gymnasts increased their body fat, and this could have influenced the indices of their athletic and technical fitness. Besides, more body fat and bigger body weight negatively affect the evaluations of the referees (Popovic, 2000; Nordin et al., 2003; Pietrzyk, 2003).

In the most effective training program the indices of difficulty of technique and training loads were slightly lower than the same indices in the less effective training program. In this period of physical training, it is worth noting the significance of the factors of training content and training load. However, registered training loads allowed establishing only the general tendencies of the improvement of sports performance in training athletes (Bügner, 2005), a more detailed analysis of interaction of training and sports performance is possible in a case study registering the plan of individual training (Banister et al., 1999; Avalos et al., 2003), and testing sports performance more often (Mester, Perl, 2000; Perl, 2001, 2004).

\section{CONCLUSION AND PERSPECTIVES}

Sports performance of 14-15-year-old athletes in rhythmic gymnastics was mostly influenced by the time for mastering competitive routines 
$(\mathrm{r}=0.836)$, however, the research did not establish differences in intensifying training. Besides the importance of integral athletic fitness, explosive strength, and strength endurance, the research established the significance of aerobic fitness $(\mathrm{r}=0.704)$ for sports performance. Moreover, the significance of body composition indices increased in comparison with previous training years: body height $(\mathrm{r}=-0.819)$, body weight $(\mathrm{r}=-0.657)$, and BMI $(\mathrm{r}=-0.836)$.

\section{REFERENCES}

Apatow, S. (2001). Why Eastern Bloc Countries Dominated the Gymnastics Field in Sydney [23 052005$].$ Internet link: www.education.ed.ac.uk/gym/papers. sa.html

Avalos, M., Hellard, P., Chatard, J. C. (2003). Modeling the training-performance relationship using a mixed model in elite swimmers. Medicine and Science in Sports and Exercise, 26, 217-238.

Balyi, I. (2001). Sport System Building and Longterm athlete development in British Columbia, Canada. Sport Med BC [10 05 2010]. Internet link: <www. sportdevelopment.org.uk $>$

Balyi, I., Hamilton, A. (2004). Long-term Athlete Development: Trainability in Childhood and Adolescence: Windows of Opportunity, Optimal Trainability. Victoria: National Coaching Institute British Columbia \& Training and Performance Ltd.

Banister, E. W., Carter, J. B., Zarkadas, P. C. (1999). Training theory and taper: Validation in triathlon athletes. European Journal of Applied Physiology, 79, 182-191.

Bügner, J. (2005). Nichtlineare Methoden in der trainingwissenchaftlichen Diagnostik: mit Untersuchungen aus dem Schwimmsport: Doctor dissertation. Postdam Univeristät.

Douda, H., Laparidis, K., Tomakidis, S. P. (2002). Long-term training induces specific adaptations on the Physique of Rhythmic Sports and female Artistic gymnasts. European Journal of Sport Science, 2 (3), $1-13$.

Edelmann-Nusser, J., Hohmann, A., Henneberg, B. (2002). Modeling and prediction of competetive performance in swimming upon neural networks. European Journal of Sport Science, 2 (2), 1-10.

Fan, L., Tang, H., Zhao, Y. (2004). Problems in the training of Chinese rhythmic gymnasts. Pre-Olympic Congress International of Sport Science. Athens.

Hellard, P., Avalos, M., Lacoste, L. et al. (2006). Assesing the limitations of the Banister model in monitoring training. Journal of Sport Sciences, 24 (5), 509-520.

Hohmann, A., Edelmann-Nusser, J., Henneberg, B. (2000). A Nonlinear Aproach to the Analysis and Modeling of Training and Adaption in Swimming. In Y. Hong and R. H. Sanders (Eds.), Proceedings of XVIII International Symposium on Biomechanics in Sports. Applied Program: Application of Biomechanical Study in Swimming (pp. 31-38). Hon Kong: Chinese University Press.
Jastrejembskaia, N., Titov, Y. (1999). Rhythmic gymnastics. Champaign: Human Kinetics.

Knoll, K., Knoll, K., Kothe, T. (2000). Grenzen der Leistungsfahigkeit des Menschen in den technischkompositorischen Sportarten. Leistungssport, 1, 33-38.

Krug, J. (1996). Entwiklungstendenzen der Trainings- und Wetkampfsysteme in den technischkompositorischen Sportarten. Zeitschrift für Angewedte Trainingswiseenschaft $\left[\begin{array}{lll}10 & 05 & 2009\end{array}\right]$. Internet link: $<\mathrm{h}$ ttp://iat.uni-leizig.de/iat/zeitschrift/hinweis.htm

Kubukeli, Z. N., Noakes, T. D., Dennis, S. C. (2002). Training techniques to improve endurance exercise performances. Sports Medicine, 32 (8), 489-509.

Kulis, Y. Y., Laurinavichyus, V. S. A., Firantas, S. G. A., Kurtinaitiene, B. S. (1988). Determination of lactic acid with an Exan-G analyser. Journal of Analytical Chemistry of the USSR, 43 (7), 1521-1523.

Mester, J., Perl, J. (2000). Grenzen der Anpassungsund Leistungsfahigkeit des Menchen aus systematischer Sicht: Zeitreihenanalyse und ein informatisches Metamodell zur Untersuchung physologischer Adaptionsprozesse. Leistungssport, 1, 43-51.

Nordin, S. M., Harris, G., Cumming, J. (2003). Disturbed eating in young, competitive gymnasts: Differences between three gymnastics disciplines. European Journal of Sport Science, 3 (5), 1-14.

Perl, J. (2004). Modelling Dynamics Systems - basic aspects and applications to performance analysis. International Journal of Sport Science in Sport, 3 (2), 19-28.

Perl, J. (2001). Per-Pot: A metamodel for simulation of load performance interaction. European Journal of Sport Science (EJSS), 1 (2), 13.

Pietrzyk, D. (2003). Relations between morphological structure and performance in female rhythmic gymnasts. Sport Kinetics, 8th International Scientitific conference Rydzyna, September 19-21.

Popovic, R. (2000). International bias detected in judging rhythmic gymnastics competition at Sydney-2000 Olympic Games. Facta Universitatis. Series. Physical Education and Sport, 1, 1-13.

Rutkauskaite, R., Skarbalius, A. (2011). Interaction of training and performance of 13-14-year-old athletes in rhythmic gymnastics. Ugdymas. Kūno kultūra. Sportas, 3 (82), 29-36.

Rutkauskaite, R., Skarbalius, A. (2009). Training sport performance of the 11-12-year-old athletes in rhythmic 
gymnastics. Ugdymas. Kūno kultūra. Sportas, 1 (72), 107-115.

Thomas, L., Busso, T. (2005). A theoretical study of taper characteristics to optimize performance. E. Tsolakidis, A. Osterburg (Eds.), Proceedings of the 6th Annual Congress of the European College of Sport Science Perspectives and Profiles (pp. 1059). Medicine Science Sports Exercise, 37 (9), 1615-1621.

Говорова, М. А., Плешкань, А. В. (2001). Специиальная физическая подготовка юных спортсменок высокой квалификации в художественной гимнастике. Москва.
Лисицкая, Т. С., Бирюк, Е. В., Новик, М. Г., Батаен, В. Г. (1982). Художественная гимнастика. Москва: ФИС.

Карпенко, Л. А. (2003). Художественная гимнастика. Москва: ФИС.

Стамбулова, В. (1999). Психология спортивной карьеры. Санкт Петербург: Центр карьеры.

Худолей, О. Н. (2004). Проблема построения процесса подготовки юных гимнастов. Физическое воспитание студентов творческих специальностей, 6, 72-79. (Харъков, сборник статей) [2004 03 15]. Internet link: $<\mathrm{h}$ ttp://lib.sportedu.ru

\title{
MENINĖS GIMNASTIKOS SPORTININKIŲ (14-15 METŲ) INTENSYVAUS RENGIMO IR PARENGTUMO OPTIMIZAVIMAS
}

\author{
Renata Rutkauskaitè, Antanas Skarbalius \\ Lietuvos kūno kultūros akademija, Kaunas, Lietuva
}

\section{SANTRAUKA}

Tyrimo pagrindimas ir hipoteze. Sportininkų ugdymo veiksmingumas priklauso nuo kryptingo rengimo vyksmo tam tikrais sportininkų rengimo etapais, valdymo, individualios sportininko adaptacijos prie pratybų ir varžybų krūvių.

Tikslas - išsiaiškinti specialiojo rengimo poveiki 14-15 metų meninės gimnastikos sportininkių parengtumo optimizavimui.

Metodai. Eksperimento metu buvo modeliuojama dviejų skirtingų rengimo programų struktūra ir registruotas sportininkių parengtumas (atletinis, techninis ir psichinis). Krūvių protokoluose buvo registruojamas choreografijai, elementų mokymuisi, varžybiniams pratimams ir atletiniam rengimui skirtas laikas per kiekvienas pratybas. Rengimo programų veiksmingumas nustatytas registruojant varžybinès veiklos realizavimą varžybų sąlygomis pagal kiekvienos rengimo programos gimnastès gaunamus taškus ir kiekvieną iškovotą vietą (nustatytą taškų skyrimą mažèjančia tvarka). Norint išsiaiškinti, ar pratybų ir varžybų krūviai atitiko varžybinės veiklos specifiką, buvo registruojamas pulso kitimas skirtingų pratybų metu.

Rezultatai. Ivairių programų sportininkès treniravosi skirtingai - reikšmingai nesiskyrè taikomų krūvių (nuo 672 iki 697 h per metus) (p < 0,001), pratybų dienų rodikliai (nuo 5,4 iki 5,6 dienų per savaitę), tačiau statistiškai reikšmingai skyrèsi sportininkių rengimo turinys - veiksmingiausioje rengimo programoje dominavo choreografinis rengimas. Statistiškai reikšmingai skyrèsi staigiosios jëgos bei jègos ištvermès, specialiosios ištvermès ir koordinacijos judamujų gebejjimų rodikliai $(\mathrm{p}<0,05)$. Kūno veiksmų ir veiksmų su ịrankiais technikos realizavimas skirtingų rengimo programų metu ir sezono pradžioje bei pabaigoje nesiskyrè $(\mathrm{p}>0,05)$.

Aptarimas ir išvados. Sportinių rezultatų siekimo etapu išryškejjo 14-15 metų meninès gimnastikos sportininkių varžybiniams pratimams tobulinti skirto laiko bei integraliojo rengimo reikšmė sportininkių varžybinės veiklos veiksmingumui. Be atletini parengtumą apibūdinančio integraliojo rodiklio, staigiosios jègos ir ištvermès rodikliu poveikio nustatyta ir aerobinio pajëgumo $(r=0,704)$ reikšmé sportiniams rezultatams. Be to, lyginant su ankstesniais eksperimentais, išryškejjo kūno kompozicijos rodiklių ir sportinių rezultatų sąsajos (ūgio $-\mathrm{r}=-0,819$, svorio $-\mathrm{r}=0,657$ ir $\mathrm{KMI}-\mathrm{r}=0,836)$.

Raktažodžiai: meninė gimnastika, rengimas, parengtumas, metamodelis.

Gauta 2012 m. rugsèjo 24 d.

Received on September 24, 2012

Priimta 2012 m. gruodžio 5 d.

Accepted on December 5, 2012
Corresponding author Renata Rutkauskaitè Lithuanian Academy of Physical Education Sporto str. 6, LT-44221 Kaunas

Lithuania

Tel +37067409104

E-mail r.rutkauskaite@1kka.lt 